\title{
Медиа-поэзия jako událost ve virtuálním i veřejném prostoru
}

\author{
Jana Kostincová (Hradec Králové)
}

\begin{abstract}
Abstrakt
Článek je věnován novému fenoménu v kontextu současné ruské literatury, fenoménu media-poezie. Mediapoezii pojímá v kontextu transmediální literatury/umění, předkládá její charakteristiku a prezentuje ji ve vztahu k tradiční tištěné literatuře i k současné digitální (elektronické) literatuře. Autorka se soustřed'uje na takové rysy této umělecké oblasti, jako jsou transmedialita, aktivismus, tematizace materiality a performativity literárníno dila i tvưrčího procesu, těsné spojení umělecké tvorby s její teoretickou reflexí. Transmediální poezie je prezentována na konkrétních príkladech z tvorby Pavla Arseňjeva, básníka, kritika, teoretika, jedné z nejzajímavějších osobností této oblasti současné ruské literární scény.
\end{abstract}

\section{Klíčová slova}

současná ruská literatura; media-poezie; elektronická literatura; performance; transmedia

\section{Abstract \\ The Media-Poetry as an Event in Virtual and Public Space}

The article approaches the topic of a new phenomenon in the context of contemporary Russian literature, the phenomenon of media-poetry. It handles it within the context of transmedia literature/art, attempts to give its characteristics in the relationship with print literary tradition as well as contemporary digital (electronic) literature. The characteristics of this area of contemporary literature stressed by the author are transmediality, activism, thematization of materiality and performativity of the work of art as well as the creative process, the connection of artistic practice with its theoretical reflection. Attention is paid to works by Pavel Arseniev, poet, critic, independent researcher, one of the most interesting figures of contemporary Russian poetic scene.

\section{Key words}

contemporary Russian literature; media-poetry; electronic literature; performance; transmedia 
Zatímco na konci 20. století se objevovaly prognózy možného, a dokonce brzkého zániku knih, konce tisku, který bude zcela nahrazen elektronickými nosiči, a dokonce i zániku literatury, kterou by nahradily multimediální projekty, na začátku 21. století se tón výrazně změnil. Je evidentní, že tisk není na ústupu, i když je samozřejmě spojen s digitálními technologiemi. Z uměleckých děl i z teoretických prací vyplývá, že tvưrčí potenciál je možné a nezbytné hledat tam, kde spolu tradiční a moderní technologie vstupují do kontaktu, kde komunikují, prolínají se.

Pro poslední roky 20. století bylo typické široce rozšířené okouzlení novými technologiemi i způsobem a rychlostí, jakými ovlivnily a změnily společenský kontext, způsob práce. Tyto změny se projevily samozřejmě i v oblasti literárního života, ve způsobu vzniku, distribuce a recepce literárních děl, ale také v proměně jejich charakteru. Devadesátá léta minulého století byla obdobím, kdy mnozí autoři a teoretici vkládali naděje do žánru hypertextu, nahlíželi právě tento žánr jako produktivní a očekávali, že se záhy projeví jeho potenciál nejen v oblasti šíření informací, ale také jeho potenciál umělecký, předpokládali, že hypertext v borgesovské tradici pomůže k obnovení narativních postupů umělecké prózy. Se začátkem 21. století dochází v oblasti elektronické literatury ke změnám, ačkoli spojení literatury a počítačové techniky přináší nadále i složitá epická díla, např. projekty I. Szilak či S. Tomasuly, experiment se nadále orientuje především na poezii. V ruském prostředí se prosazuje fenomén media-poezie (media-poetry, медua-поэзия). Lze říci, že elektronická literatura prošla specifickým vývojem a vyprofilovala se způsobem, který potvrzuje nedávné tvrzení Nicka Montforta o tom, že elektronická literatura je propojená s různými regionálními tradicemi, že její místní odlišnosti souvisejí s technologiemi stejně jako s jazykem a literárními tradicemi. ${ }^{1}$

Směr, kterým se ruská elektronická literatura ubírá v posledních letech, tedy v době webu 2.0, charakterizovaného především sociálními sítěmi, také potvrzuje slova Lva Manoviche, o tom, že softwarem dnešního tvưrčího experimentu spojeného s počítačovými technologiemi je historická avantgarda, především její nejradikálnější projevy v tvorbě ruské a německé. ${ }^{2} \mathrm{~V}$ kontextu ruské literatury se po hypertextových experimentech i po experimentu v oblasti kolektivního autorství a interaktivních textových her devadesátých let minulého století významně prosazuje proud zdůrazňující spojení s tradicí historické avantgardy a také s moskevským konceptualismem, proud, který se orientuje na performativitu a multimedialitu. Významnou proměnu do oblasti elektronické literatury přinesly právě sociální sítě, které hrají velkou roli v rozšíření uměleckého slova zpět do „offlinu“, tedy z virtuálního prostředí do reálného veřejného prostoru, zejména městského. Internet už není považován za archiv literárních textů a literární salon, jak tomu bylo ještě v době jeho počátků. Počítače samozřejmě proměnily způsob produkce, distribuce i recepce literárních textů, umožnily rozšíření amatérské tvorby, zároveň ale sociální sítě přinesly jisté oživení reálných kontaktů a setkávání off-line. Právě prostřednictvím sociálních sítí se svolávají nejrůznější happeningy, organizují festivaly, případně

1 MONTFORT, Nick: „E-lit je propojená s různými literárními tradicemi.“ O elektronické literatuře s Nickem Montfortem. Česká literatura 63, 2015, č. 6, s. 953.

2 MANOVICH, Leo: Avant-garde as Software. manovich.net, http://www.manovich.net/articles.php [online]. [cit. 14. 2. 2013]. 
amatérské akce typu guerilla poetring, které různými způsoby rozšiřují umělecké slovo ve veřejném prostoru. Tyto akce mohou mít charakter hry, jež si neklade jiné cíle než čistě dekorativní, jak je tomu v případě českého guerilla poetring ${ }^{3}$. Nebo mohou spojovat uměleckou výpověd' s občanským gestem, s aktivizmem, jak tomu často bývá právě v ruském kontextu. Básník a kritik Alexandr Skidan dokonce současnou ruskou poezii charakterizuje jako repolitizovanou a tvrdí, že je obtížné odlišit politickou akci od akce umělecké, protestní shromáždění od performance, transparent od básnické výpovědi v duchu dada. ${ }^{4}$ Politický rozměr ale není znakem, který by ruský kontext odlišoval, i slovenská badatelka Bogumiła Suwara zdůrazňuje mnohostrannost a otevřenost této umělecké oblasti „nasmérované na procesualitu, performanci, na zasahováni do problematických oblasti společenského, občanského života“, hovoří také o „uměni, pro které je důležitějši etapou než exprese právě shromažd’ováni dat, poznatků a navazováni komunikace s vědeckým nebo občanským diskurzem". ${ }^{5}$

Právě A. Skidan opakovaně zdůrazňuje nejen politický aspekt současné poezie, ale její otevřenost. V přednášce Поэзия другими средствами, organizované petrohradským almanachem [Translit], uvádí: «Современная поэзия устремлена к непоэтическому и даже $\kappa$ невербализованному.» ${ }^{6} \mathrm{O}$ šíři současné poezie, o tom, že neustále směřuje k překračování hranic, píše i Mark Lipoveckij: «Современная поэзия постоянно выходит за свои предель, не только через перформатизм, но и через размъьвание грании между стихами u прозоц̌». ${ }^{7}$ Tvrdí také, že poezie vytváří nové chápání politického, politická lyrika podle jeho slov není spojena ani tak s reakcí na politická témata, jako spíše se snahou vymezit identitu subjektu nikoli jako pozorovatele nebo oběti politických procesů, ale jako figury aktivního odporu a jednání. ${ }^{8}$

Propojení literatury a moderních technologií se tedy stalo faktem, neznamená ovšem, že by se literatura částečně přenesla do virtuálního světa a že by básnické slovo nadále existovalo bud' v podobě tištěné na stránkách knih a časopisů anebo bylo dostupné na obrazovce počítače, tabletu či smartphonu. Umělecká díla, která vznikají v počítačovém prostředí, velice často vstupují do veřejného prostoru, a to v podobě textu distribuovaného v městském prostoru prostřednictvím nálepek, případně nápisů na chodnících, na stěnách. Objevují se i formy distribuce textů, které ve veřejném prostředí odrážejí fluiditu prostředí počítačového, tematizují proměnlivost a pomíjivost - texty na chodníku, jež se stávají viditelnými v dešti, básnické texty, psané na listech stromů. Umělecké slovo

3 PIORECKÝ, Karel - PIORECKÁ, Kateřina: Guerrilla poetry(ing). Postdigitální hra ve veřejném prostoru? Tvar 21, 2016, http://itvar.cz/guerrilla-poetrying-postdigitalni-hra-ve-verejnem-prostoru/ [online]. [cit. 8. 1. 2017].

4 SKIDAN, Aleksandr: «Kto govorit?» Poètičeskij sub”jekt i politika soobščestva. Ot redaktora. NLO 124, 2013. http://magazines.russ.ru/nlo/2013/124/16s.html [online]. [cit. 30. 9. 2016].

5 SUWARA, Bogumiła: E-INTERVIEW. In: Husárová, Z. - Mencía, N. (eds.): ENTER. Kreatívny manuál pro súčasnú elektronickú literatúru. ENTER No. 18, roč. V, s. 90-95.

6 SKIDAN, Aleksandr: Poèzija drugimi sredstvami. https://vimeo.com/73294175 [online]. [cit. 11. 9. 2016].

7 LIPOVECKIJ, Mark: FB kak metažanr, ili Putem preformativa. http://www.academia.edu/12798390/ [online] [cit. 2. 5. 2016].

8 Tamtéž. 
se $\mathrm{k}$ recipientům dostává prostřednictvím performancí, galerijních instalací. Pro tuto oblast tvorby je typické, že díla neexistují pouze v jedné formě, ale jsou zpřístupněna paralelně prostřednictvím několika různých médií, tedy ve formátu transmedia. Divákovi - čtenáři mohou být dostupná jak ve formě počítačově generovaného textu na internetu, tak v knižní podobě, která zachycuje určitý okamžik existence textového generátoru, a tak tematizuje jeho proměnlivost, ve formě pouliční performance, instalace v galerii a samozřejmě často také jako fotografický záznam či videozáznam dokumentující tyto performance a instalace. Americká badatelka Marjorie Perloff používá pro tento typ umění označení differential texts, charakterizuje je jako texty existující v různých materiálních formách, přičemž ani jedna z jejich variant není definitivní. Jako příklad uvádí tvorbu současného amerického konceptualisty Kennetha Goldsmithe, její tištěné i digitální verze, stejně jako instalace s prvky vizuálními a zvukovými. ${ }^{9}$ Transmediální umění tedy znamená i nový pohled na digitální technologie. Umění již překonalo fázi okouzlení technikou a jejími možnostmi, nesoustřed’uje se na technologické inovace a experimenty, netematizuje techniku a její možnosti, ale využívá digitální technologie jako jeden z prostředků, jak uvádí Florian Cramer, nastává fáze post-digitální, která maže rozdíly mezi „novými“" a „starými“ médii. ${ }^{10}$

Na internetové stránce představující ruskou mediapoezii je tato charakterizována jako nový směr v současném umění, v němž se spojují moderní technologie s cílem vytvořit syntetické dílo jazykového umění, které reflektuje současnost novými metodami. ${ }^{11}$ Důraz je kladen na formu, materialitu neboli médium takového uměleckého díla. Materiální charakteristiky pak vedou k tomu, že media-poezie není slovem, ale událostí, která nemůže být zprostředkována na papíře nebo na videozáznamu - její divák se stává plnoprávným účastníkem této události a jejím spoluautorem. Nová poezie hledá svou podobu v takových formách, jako jsou media-art, sound-art, science-art, v generativním umění a v umění performance.

Na jaře roku 2016 se v Petrohradu konal druhý ročník Mezinárodního festivalu mediapoezie 101. Форматирование памяти/101. Formatting memory. 101 v názvu organizátoři vysvětlují jako odkaz k systému binárního kódu a způsobu přenosu informace. Cílem festivalu bylo zkoumání nových forem jazyka v digitální době, syntéza poezie, umění a médií, ročník byl věnován tématu formátování paměti. ${ }^{12} \mathrm{Z}$ anotace je patrné, že pro tento typ umění je skutečně důležitá multimedialita, ale také propojení kyberprostoru a reálného prostoru, odhmotněnost stejně jako předmětnost uměleckých artefaktů, materializované slovo i pomíjivost ve hře se světlem, zvukem, slovo jako objekt i slovo jako zvuk. Festival 101. Форматирование памяти/101. Formatting memory byl tedy událostí nejen ve smyslu setkání tvůrců a teoretiků na workshopech, výstavách, zvukových instalacích, autorských čteních, na přednáškách. Právě jeho název odkazuje i k tomu typu

9 PERLOFF, Marjorie: Screening the Page/Paging the Screen: Digital Poetics and the Differential Text. In: New Media Poetics: Contexts, Technotexts, and Theories. Cambridge and London: MIYT Press, 2006, s. $143-164$.

10 CRAMER, Florian: What is „Post-digital“? APRJA. 3. 2014, č. 1. http://www.aprja.net/?p=1318 [online] [cit. 22. 4. 2016].

11 Mediapoèzija. Media-poetry. http://media-poetry.ru/?page_id=265 [online]. [cit. 30. 12. 2016].

12 101. Formatting memory. http://media-poetry.ru/ [online]. [cit. 30. 12. 2016]. 
události, který analyzuje K. Hayles. Jedná se o technický aspekt existence - neexistence elektronické tvorby, její procesuální charakter spojený s tím, že dílo elektronické literatury neexistuje ve stejném smyslu jako tištěná kniha. K. Hayles hovoří o formě pre-existence tištěného média v kontrastu s médiem digitálním. V tomto smyslu je i téma paměti a jejího „formátování“ specifické, zároveň odkazuje k proměnám toho, co je do paměti uloženo. Využitím fotografie z filmu Total Recall na plakátech i na webových stránkách pak organizátoři otevřeli i téma moderních technologií a záměrné manipulace paměti.

Tento festival se účastí ruských i zahraničních umělců i badatelů zařazuje zároveň mezi akce, které dokládají mezinárodní charakter transmediálního umění, ovšem zároveň demonstrují jistou uzavřenost této komunity do sebe. Tato uzavřenost byla charakteristická pro elektronickou literaturu i pro tvorbu spojenou s digitálními technologiemi v širším smyslu od samého jejího počátku; umělci často píší teoretické práce, v nichž svou tvorbu reflektují, akademici, věnující se teorii nových médií, se pouštějí do tvůrčích experimentů. Každoroční konference pořádané Organizací elektronické literatury (ELO) také mají složku vědeckou a uměleckou, součástí jejich programu jsou vedle přednášek a workshopů také autorské performance, instalace.

K osobnostem, které významně formují ruskou transmediální scénu, patří Pavel Arseňjev a Natalia Fedorova, oba jsou jak aktivními tvưrci, tak i teoretiky, pracujícími v oblasti literatury a nových médií. Oba patří ke spoluorganizátorům literárních festivalů, performancí a workshopů, včetně výše uvedeného festivalu petrohradského media-poezie, oba také publikují v almanachu [Translit], jehož je Arseňjev šéfredaktorem. N. Fedorova, která charakterizuje své umělecké zaměření termínem language media artist, dokázala do značné míry zpopularizovat v ruském prostředí elektronickou tvorbu, přivést ji i na akademickou půdu (působí na Fakultě svobodných umění a věd Petrohradské státní univerzity), experimentovala v oblasti překladu počítačově generovaných textů (ve spolupráci s jedním z nejznámějších odborníků v této oblasti spojující techniku a umění, Američanem Nickem Montfortem). Pavel Arseňjev ve svých aktivitách vytváří nesmírně zajímavou směs literárněvědných a filozofických úvah, multimediální tvorby, performancí, svou činnost uměleckou a aktivistickou realizuje především v rámci skupiny Лаборатория Поэтического Ажиионизма, která působí od roku 2008 v Petrohradu. Toto seskupení, jehož vưdčí osobností je právě Arseňjev se označuje jako „pracovni společenstvi básniků, umělcư a filozofư, kteřri si kladou za cíl překonat odcizeni každodennosti prostřednictvím zaplněni městského prostoru poezin ${ }^{*} .{ }^{13}$ Ve svých textech i performancích se odvolávají na francouzské hnutí situacionistů a jejich teorii derive - narušení stereotypního vnímání a užívání městského prostoru. Arseňjev zdůrazňuje, že některé básně nejsou určeny k tomu, aby existovaly na stránce knihy: „Současná městská kultura existuje v mnoha hybridních formách, v nichž směsi videozáznamu a muzejni expozice, performance a poulični akce, koncertu a sociologického průzkumu spiše jedna druhou stř́daji, než aby se stabilizovaly a ukazovaly jasně definovaný žánrový tvar. "14 Pavel Arseňjev je zároveň šéfredaktorem literárněvědného almanachu [Translit], který vychází ve stejnojmenném nezávislém nakladatelství od roku 2005 a který

13 Laboratorija Poètičeskogo Akcionizma. https://poetryactionism.wordpress.com/ [online]. [cit. 4. 2. 2015].

14 ARSEN'JEV, Pavel: Kategoričeskij performativ. https://www.facebook.com/events/481589171997107/ [online]. [cit. 6. 4. 2014]. 
byl zpočátku zaměřen především na poezii, postupně se jeho tematický okruh rozšiřoval na jazyk, medialitu, na témata z oblasti sociologie a antropologie literatury. V [Translitu] jsou zveřejňovány i překladové texty, např. P. Bourdieu, autoři z okruhu americké Language School. Z hlediska pojednávaného tématu jsou relevantní především deváté číslo almanachu z roku 2011, které bylo věnováno tématu literatury a digitální technologie, a dále čísla 18 a 19. V 18. čísle z roku 2016, nazvaném Драматургия письма, byly v oddíle Теория писъма publikovány např. článek Jekatěriny Samigulinové Асемическое писъмо: новая пост-литература, Dmitrije Žukova Пустой знак в поэзии и теории множеств, ale také text Alexeje Konakova Харитонов как предтеча радикального акиионизма, jeden z příkladů, kdy se autoři z okruhu [Translitu], podobně jako autoři patřící ke skupině Лаборатория Поэтического Акиионизма hlásí k tradici ruské neoficiální kultury druhé poloviny minulého století a zároveň deklarují snahu překonat dělení kultury na oficiální a neoficiální. 19. číslo almanachu má vyjít pod názvem Обвектно-ориентированная поэзия, v anotaci, která je ohlašuje, se objevují otázky kladoucí připravované texty do kontextu ruské historické avantgardy: «Кто как не русские авангардисты столько говорили о вещах, предметности и материале (в противопоставлении сознанию, значению и конструкиии)? Чем как не проектом эпистемологического упразднения субъекта и преодоления отчуждения вещей было движение производственной литературы (литературы факта)? Кто как не Виктор Шкловский требовал отвоевания у привычки суверенной вешности и возврашения «каменности камня», рассчитьвая в этом на помощь искусства?» ${ }^{15}$ Pojednávat budou autoři také například o apropriaci textů v tvůrčí praxi současných konceptualistů. Opět se tedy potvrzuje, že právě historická avantgarda i konceptuální umění patří k inspiračním zdrojům autorů tohoto okruhu i k tématům jejich teoretické reflexe.

Kategorie materiality je, spolu s performativitou, tou kategorií, která velmi dobře demonstruje vzájemnou interakci a komunikaci starých a nových médií. V činnosti uvedených autorských seskupení je patrná neustálá konfrontace tradičních a nových médií, autoři v uměleckých akcích i v teoretických pracích zkoumají různé aspekty a možnosti performativity, a to nejen v podobě živé literární události (autorského čtení, happeningu, transmediální performance), ale také ve fenoménu performance writing, který umožňuje syntézu obou kategorií, materiality i performativity, tím, že zkoumá materialitu psaní, vztah mezi psaním a vizuálním uměním, instalací, sound artem, performancí16.

Právě Pavel Arseňjev v mnoha svých dílech tematizuje materialitu básně - básnického slova, procesualitu, lze říci, že se do jisté míry přibližuje právě k performance writing. Jedná se především o dílo Примечания переводика, označené jako video- a texto-montáž (видео а текстомонтаж), v němž Arseňjev pracuje s textem Modré a Hnědé knihy Ludwiga Wittgensteina. Výběr právě tohoto díla není v žádném případě náhodný, Arseňjev nejen v této práci prokazuje, že jsou mu blízké Wittgensteinovy úvahy o významu, o jazykových hrách. Na Wittgensteina se odvolává i ve svých teoretických textech, např́iklad v článku nazvaném «Выходит современный русский поэт и кагбэ нам намекает»: К прагматике

15 Ob"jektno-orieentirovannaja poèzija. [Translit] http://www.trans-lit.info/vypuski/19-translit [online]. [cit. 29. 12. 2016].

16 BERGVALL, Caroline: What Do We Mean by Performance Writing? http://www.carolinebergvall.com/content/text/BERGVALL-KEYNOTE.pdf [online]. [cit. 2. 3. 2015]. 
художественного высказывания. V něm se Arseňjev zamýšlí nad současnou poezií a nahlíží ji opět perspektivou události - tentokrát reálné situace události výpovědi. Na příkladech několika událostí z petrohradského literárního života (setkání básníků čtoucích a komentujících cizí texty, elektronická publikace textů v sociální síti, vybízející k jejich kolektivnímu dotváření) se snaží dokázat, že pojem a praxe ozvláštnění (остранение) se mají rozšíríit na úroveň pragmatiky, tedy na úroveň reálné situace události výpovědi. Arseňjev píše o ozvláštnění samotného rámce uměleckosti, o praxi, která se týká nejen definice umění, ale „sociálni situace umělecké výpovědi“. ${ }^{17}$

$\mathrm{K}$ nejnovějším uměleckým pokusům Pavla Arseňjeva patří i instalace označená jako Cyklus objektů Материальна поэзия, kterou autor uvádí citátem z G. W. F. Hegela: «Если они действительно хотели выразить в словах этот клочок бумаги, то это невозможно, потому что чувственное „это“, которое подразумевается, недостижимо для языка. При действительном осуществлении попытки выразить в словах этот клочок бумаги он от этого истлел бы, те, кто начал бы описание его, не могли бы закончить это описание, а должны были бы предоставить это другим, которые в коние кониов сами признали бъ, ито говорят о веши, которой нет.» Využitím apropriovaného textu v instalaci pak Arseňjev vytváří umělecký artefakt, který souzní s teoretickými úvahami o eliminaci subjektu a nástupu od něj se osvobodivšího materiálu, které se mají rozvinout v připravovaném čísle almanachu [Translit].

Několik př́kladů z tvorby současných ruských autorů je, domnívám se, důkazem toho, že vztah literatury a moderních počítačových technologií se od devadesátých let minulého století proměnil. Literatura nezanikla, nepřenesla se do virtuálního prostředí, ale ve spojení tradice a počítačové technologie se jedna její oblast proměnila. V novém kontextu hledá nové možnosti umělecké syntézy, zkoumá hranice a možnosti jazyka, provokuje, zpochybňuje, znejistuje. Je patrné, že uvedené př́klady z tvorby současných ruských autorů svědčí o tvůrčí energii, teoretické fundovanosti, o odhodlání vést dialog s předchozí literární tradicí i vstupovat do dialogu se současnou společností, vědou, technikou.

\section{Literatura}

ARSEN'JEV, Pavel: «Vychodit sovremennyj russkij poèt i kakbè nam namekajet»: K pragmatike chudožestvennogo vyskazyvanija. NLO 6, 2013 [online]. [cit. 4. 6. 2015]. Dostupné z: http://www.nlobooks.ru/node/4185.

ARSEN'JEV,Pavel: Kategoričeskijperformativ. https://www.facebook.com/events/481589171997107/ [online]. [cit. 6. 4. 2014].

BERGVALL, Caroline: What Do We Mean by Performance Writing? http://www.carolinebergvall. com/content/text/BERGVALL-KEYNOTE.pdf [online]. [cit. 2. 3. 2015].

CRAMER, Florian: What is „Post-digital“? APRJA. 3. 2014, č. 1. http://www.aprja.net/?p=1318 [online] [cit. 22. 4. 2016].

17 ARSEN'JEV, Pavel: «Vychodit souremennyj russkij poèt i kakbè nam namekajet»: K pragmatike chudožestvennogo vyskazyvanija. NLO 6, 2013, http://www.nlobooks.ru/node/4185 [online]. [cit. 4. 6. 2015]. 
HAYLES, Katherine: The Time of Digital Poetry: From Object to Event. In: MORRIS, Adalaide SWISS, Thomas (eds.): New Media Poetics: Contexts, Technotexts, and Theories. Cambridge: MIT Press, 2006, s. 181-209.

Laboratorija Poètičeskogo Akcionizma. https://poetryactionism.wordpress.com/ [online]. [cit. 4. 2. 2015].

LIPOVECKIJ, Mark: FB kak metažanr, ili Putem preformativa. http://www.academia.edu/12798390/ [online] [cit. 2. 5.2016].

MANOVICH, Leo: Avant-garde as Software. manovich.net, http://www.manovich.net/articles.php [online]. [cit. 14. 2. 2013].

Mediapoèzija. Media-poetry. http://media-poetry.ru/?page_id=265 [online]. [cit. 30. 12. 2016].

MONTFORT, Nick: „E-lit je propojená s různámi literárními tradicemi. “ O elektronické literatuře s Nickem Montfortem. Česká literatura 60, 2015, č. 6, s. 951-960.

Ob”jektno-orientirovannaja poèzija. [Translit] http://www.trans-lit.info/vypuski/19-translit [online]. [cit. 29. 12. 2016].

PERLOFF, Marjorie: Screening the Page/Paging the Screen: Digital Poetics and the Differential Text. In: New Media Poetics: Contexts, Technotexts, and Theories. Cambridge and London: MIYT Press, 2006, s. 143-164.

PIORECKÝ, Karel - PIORECKÁ, Kateřina: Guerrilla poetry(ing). Postdigitální hra ve veřejném prostoru? Tvar 21, 2016, http://itvar.cz/guerrilla-poetrying-postdigitalni-hra-ve-verejnem-prostoru/ [online]. [cit. 8. 1. 2017].

SKIDAN, Aleksandr: «Kto govorit?» Poètičeskij sub”jekt i politika soobščestva. Ot redaktora. NLO 124, 2013. http://magazines.russ.ru/nlo/2013/124/16s.html [online]. [cit. 30. 9. 2016].

SKIDAN, Aleksandr: Poèzija drugimi sredstvami. https://vimeo.com/73294175 [online]. [cit. 11. 9. 2016].

SUWARA, Bogumiła: E-INTERVIEW. In: Husárová, Z. - Mencía, N. (eds.): ENTER. Kreatívny manuál pro súčasnú elektronickú literatúru. ENTER No. 18, roč. V, s. 90-95.

101. Formatting memory. http://media-poetry.ru/ [online]. [cit. 30. 12. 2016].

\section{Mgr. Jana Kostincová, Ph.D.}

Katedra ruského jazyka a literatury

Pedagogická fakulta, Univerzita Hradec Králové

Rokitanského 62, 500 03, Hradec Králové, Česká republika

jana.kostincova@uhk.cz 